\title{
Income Growth-Financial Stability Nexus: The Role of Institutional Quality in Emerging Economies
}

\author{
Elias A. Udeaja PhD \\ Research Department, Central Bank of Nigeria \\ Ben-Obi Onyewuchi A. \\ Research Department, Central Bank of Nigeria
}

\begin{abstract}
Motivated by the mixed evidence on growth-finance nexus, we explore the case of 23 emerging countries to offer robust insight on the extent to which financial stability(instability) induce or impede income growth. Exploring a dynamic panel estimation technique using system GMM estimator, we find both the banking segment of the financial system captured as non-performing loan and the non-banking segment measured via stock market volatility as viable underlying sources of financial instability causing declining income growth in emerging markets. Quite an interesting finding, however, is the potential of institutional quality as viable for alleviating the probable adverse effects of financial instability on income growth, particularly via corruption control, political stability, and voice of accountability.
\end{abstract}

Keywords: Financial stability(instability); Institutional quality; Emerging markets; Dynamic panels; Income growth

JEL Codes: C33, E01, E44, O11, O16

DOI: $10.7176 /$ RJFA/12-14-08

Publication date:July $31^{\text {st }} 2021$

\section{Introduction}

A major fallout from the financial crises of 1990s and global crises of 2007 is that an unstable financial system often resulted in financial crisis with potential dire implications for economic growth. In other words, a stable financial sector or financial sector stability has been widely acknowledged as necessary for the efficient functioning of the financial sector, which is indispensable for economic development. Hence, the progressively accelerated growth recorded by the emerging economies accounting for 43.2\% of global GDP in the year 2000 to about $59.65 \%$ in 2019, with the figure projected to rise to $62.52 \%$ in 2023 (see IMF, 2019; World Bank, 2019). This has been attributed to notable efforts on the emerging economies over the past one-and-a-half decades to reform their financial system. Thus, quite a number of the extant literature on income growth-financial stability nexus has continues to affirm the widespread assumption that a positive relationship exists between income growth and financial stability (see for example, Zhu et al., 2020; Chu, 2019; Sotiropoulou et al., 2019; Alsamara et al., 2019; Mollaahmetoglu \& Akcair, 2019; Batuo et al., 2018; Ranjbar \& Rassekh, 2017; Seven \& Yetkiner, 2015; Creel et al., 2015; Samargandi et al., 2014; Adu et al., 2013).

However, in addition to lack of consensus in the literature on which indices of the financial system is the most appropriate to capture financial stability (instability), a number of the existing studies have suggested that the role of finance in economic growth is weakening and, in some cases negative, due to omission of some fundamentals in the nexus for instance institutional quality (see Breitenlechner et al., 2015; Rousseau \& Wachtel, 2011). From the theoretical standpoint, the role of institutional quality in growth-finance nexus hypothetically rests on the assertion that, sound institution can help enforce financial contracts, support financial intermediation, and reduce transaction cost. This will consequently help in strengthening the stability of the financial system which is a prerequisite for enhancing the efficient allocation of resources in a more rapid accumulation of physical and human capital, as well as, fostering technological progress, all of which in turn feed into economic growth.

In attempt to validate or refute the above hypothesis, this study is using the sample of twenty-three (23) emerging economies to contribute to the literature in twofold. First, the bulk of the previous studies on the subject matter has continue to assume that financial stability (instability) is same as financial development and most often employed variables that measure financial depth, whereas the indictors of financial stability were mainly about the financial system's efficiency and solidity, which is key to increasing public confidence in the financial system (see Creel et al., 2015). Motivated by the four competing theories of financial structure, namely; bank -based, market-based, financial services, and law and finance views, constructed based on the role of banks and securities markets, this study measures financial stability both from the perspective of banking and non-banking segments of the financial system. The essence is to understand in relative term which segment of the financial system (i.e. banking \& non-banking sector) constitute source of stability (instability) to financial system and whether they vary in their potential as incentive or detrimental to growth. 
Secondly, we test the hypothesis that, improving institutional quality via the rule of law index would strengthen the stability of financial system and consequently lead to higher rates of growth. However, unlike previous studies, we test whether the stability of financial system and quality of institution are individually beneficial to growth compared to their complimentary role in the quest for increasing income growth. In addition to the rule of law index which capture the perceptions of the extent to which agent have confidence in and abide by the rule of society, we also consider a number of alternative measures of institutional quality for consistent and robustness sake.

Finally, the choice of the emerging markets as the investigated economies is motivated by the uneven levels of financial structure and institutional quality across the globe, hence our preference for the sample of countries with homogeneity in terms of real GDP per capita, financial development and institutions. In view of this, among others, we use the sample of twenty-three (23) emerging economies to test whether the potential of financial stability for explaining income growth is sensitive to the choice of the indicator of financial stability, as well as, the degree of institutional quality in the investigated economy. To achieve this, we estimated an augmented growth regression via both difference and system GMM estimators.

The remainder of the paper is structured as follows: Section 2 provides literature review on the findings of previous studies. Section 3 explains the data and offers some preliminary analysis. Section 4 is model specification and estimation procedures while section 5 presents and discusses the empirical findings of the paper, and Section 6 concludes the study.

\section{Brief literature review of related studies}

There has been increasing empirical efforts supporting the hypothesis that the development of finance induces a better allocation of resources, mobilizes savings, and can reduce risks and facilitate transaction, which in turn promote economic growth (see for example, Zhu et al., 2020; Mollaahmetoglu \& Akcair, 2019; Botev et al., 2019; Chu, 2019; Batuo et al., 2018; Ranjbar \& Rassekh, 2017; Creel et al., 2015; Seven \& Yetkiner, 2015; Samargandi et al., 2014; Adu et al., 2013; Odeniran \&Udeaja, 2010; Khan et al., 2005; Ibrahim \& Alagidede, 2018; Madsen et al., 2018; Ono, 2017; Yang \& Yi, 2008). However, in addition to some scepticism that the link between finance and economic growth has been exaggerated (Rodrik \& Subramanian, 2009; Stiglitz, 2000; De Gregorio \& Guidotti, 1995), the vast of the extant studies has continued to assume financial stability interchangeably with financial development even though both means different things. In other words, financial stability constitutes an important pillar of financial development which, according to Kablam (2010), ensures that financial risks do not outweigh returns.

However, even when literature appears to distinctly focus on the concept of financial stability, there is still no clear-cut conclusion on the relationship between financial stability and economic growth. Using the case of European Union, Creel et al. (2015) for example, find positive but insignificant impact of financial stability on growth when financial stability is measured as Z-scores, but negative and significant impact financial stability (instability) on growth when financial stability is defined as non-performing loan. Also, while Ang (2008), Samargandi et al. (2014), Kaushal \& Pathak (2015) and Rehman et al. (2015) were unanimous in their respective findings of positive impact of financial stability on economic growth, Yucel (2009) is of the view that financial stability(instability) can as well cause decreasing economic growth.

The lack of consensus on the extent to which financial stability(instability) induce(impede) growth has continued to fuel debate on whether there are other factors that matter for complementing the nexus. Rooting on this line of argument are literature relating institutional quality to financial stability and the antecedent impact of the later on economic growth (see Demetriades \& Law, 2006; Ahlin \& Pang, 2008; Compton \& Giedeman, 2011; Anwar \& Cooray, 2012; Haini, 2019). The crux of this strand of literature is that the financial system can indirectly influence economic growth through institutional development. What therefore constitute source of concern in this present study is whether it is more beneficial to treat financial stability and institutional quality as substitute or compliment in the growth process. More so, we hypothesized that the complementary role of financial stability-institutional quality in the growth process is likely to be sensitive to the choice of indicator of financial stability that is under consideration.

\section{Data and Preliminary Analysis}

As earlier pointed out, the concept of financial stability remains diverse both from theoretical and empirical perspectives, and particularly when linking it to economic performance (Ang, 2008; Creel et al., 2015). Since one of the novelties of this study lies on whether the nexus between income growth and financial stability is subject to the choice of indicator for the latter, this study utilizes three alternative indicators of financial stability. The first is the ratio of non-performing loans to gross loans often refers to as non-performing loan (NPL). The suitability of this indicator as a measure of financial stability(instability) hinges on its relevant as warning signal for systematic banking insolvency (see Alsamara et al., 2019; Cihak \& Schaeck, 2010). However, while the NPL capture the banking segment of the financial system, we measure financial stability(instability) from the 
perspective of non-banking segment using stock market volatility index (SMV). This which define the second indicator of our financial stability(instability) was measured as 360-day standard deviation of the return on the national stock market index. We further explore a composite form of these individual indicators of financial stability(instability) such as Z-score to generate our third indicator of financial stability considered in this study. The Z-score according to Creel et al. (2015) combines the banking and stock market perspectives to measuring financial stability(instability). Thus, the Z-score is a composite of (i) banks' profitability; (ii) capital ratio; and (iii) return volatility.

In addition, this study employs an index of rule of law as contained in the World Governance Indicators (WGI) to proxy for institutional quality. Alternative measures of institutional quality considered include, control of corruption, government effectiveness, political stability and absence of violence, regulatory quality, and voice of accountability. The indicator for income growth is measured as the log of the first difference real GDP per capita (log first difference). For a just comparison of our findings with inference drawn from the previous studies, we further control for a few conventional determinants of growth. The control variables include physical capital (PK) measured using gross fixed capital formation as a ratio of GDP and human capital (HK) measured as secondary school enrolment as a ratio of gross school enrolment. Other are government consumption (GC) expenditure as ratio of GDP, credit to private sector (CPS) as a ratio of GDP, inflation rate (INFL) to reflect macroeconomic environment and trade openness (TOP) measured as sum of export and import over GDP to capture the importance of international factor in influencing economic activities.

All the data are annual frequency of balanced panel of 23 emerging economies mainly sourced from World Bank Group online database for the period between 1996 and 2018. Although, Morgan Stanley Capital International Emerging Market Index (MSCI Index) suggests that 26 developing countries qualify as emerging markets, ${ }^{1}$ but for the availability of data only 23 of these 26 emerging countries were captured in this paper. Presented in Tables $1 \& 2$ is a basic statistical summary of each of the variables under consideration as well as their correlation matrix. As can be observed in the tables, the mean of the GDP per capita is approximately 9170 US dollar and the standard deviation appears to be quite large. Regarding other variables, the variation across time and countries appears to be reasonable.

Table 1. Descriptive Statistics

\begin{tabular}{|c|c|c|c|c|}
\hline & Mean & Std. Dev. & Min. & Max. \\
\hline \multicolumn{5}{|c|}{ Growth variable and its conventional determinants } \\
\hline GDP/per capita (US\$) & 9170.40 & 6617.89 & 711.93 & 30054.90 \\
\hline Physical capital & 23.04 & 6.33 & 11.07 & 45.69 \\
\hline Human capital & 85.38 & 19.63 & 9.29 & 130.44 \\
\hline Government consumption & 14.92 & 4.37 & 5.69 & 30.00 \\
\hline Credit to private sector & 52.90 & 40.31 & 0.12 & 164.18 \\
\hline Inflation rate & 6.62 & 9.78 & -1.74 & 85.75 \\
\hline Trade openness & 68.11 & 39.88 & 15.64 & 220.41 \\
\hline \multicolumn{5}{|c|}{ Financial stability indictors and institutional quality variable } \\
\hline Non -performing loan (NPL) & 11.69 & 7.20 & 0.02 & 96.68 \\
\hline Stock market volatility index (SMV) & 24.39 & 12.43 & -0.81 & 107.31 \\
\hline Z-score & 11.69 & 7.20 & 0.02 & 96.68 \\
\hline Rule of Law (INST) & 0.02 & 0.62 & -1.10 & 1.43 \\
\hline
\end{tabular}

This table presents the statistical summary of the variables under consideration including their mean, standard deviation (Std. Dev.), maximum and minimum statistics

Table 2. Correlation Coefficients

\begin{tabular}{|c|c|c|c|c|c|c|c|c|c|c|c|}
\hline & GDPC & $\mathrm{PK}$ & $\mathrm{HK}$ & $\mathrm{GC}$ & CPS & INFL & TOP & FSB1 & FSB2 & FSB3 & INST \\
\hline GDPC & 1 & & & & & & & & & & \\
\hline PK & 0.03 & 1.00 & & & & & & & & & \\
\hline HK & $0.57 * *$ & 0.05 & 1.00 & & & & & & & & \\
\hline GC & $0.62 * *$ & $-0.14 * *$ & $0.51 * *$ & 1.00 & & & & & & & \\
\hline CPS & $0.12 * *$ & $0.30 * * *$ & $0.19 * * *$ & $0.12 * * *$ & 1.00 & & & & & & \\
\hline INFL & $-0.17 * *$ & $-0.12 * *$ & $-0.16 * *$ & $-0.14 * *$ & $-0.28 * *$ & 1.00 & & & & & \\
\hline TOP & $0.25 * *$ & $0.17 * *$ & $0.17 * *$ & $0.16^{* *}$ & $0.31 * *$ & $-0.17 * *$ & 1.00 & & & & \\
\hline FSB1 & $-0.18 * *$ & $-0.11 * *$ & $-0.36 * *$ & $-0.12 * *$ & 0.02 & $0.10 * *$ & 0.02 & 1.00 & & & \\
\hline FSB2 & -0.06 & $-0.11 * *$ & -0.06 & 0.03 & $-0.22 * * *$ & $0.46 * * *$ & $-0.16 * * *$ & $0.23 * * *$ & 1.00 & & \\
\hline FSB3 & $-0.18 * * *$ & 0.04 & 0.01 & -0.04 & $0.10 * *$ & $-0.10 * *$ & -0.04 & $-0.17 * * *$ & $-0.09 * *$ & 1.00 & \\
\hline INST & $0.61 * * *$ & $0.22 * * *$ & $0.33 * * *$ & $0.33 * *$ & $0.31 * * *$ & $-0.21 * * *$ & $0.47 * * *$ & $-0.11 * * *$ & $-0.16 * * *$ & $-0.16 * * *$ & 1.00 \\
\hline
\end{tabular}

For the financial stability indicators, the mean statistics for non-performing loan (FSB_1), stock market

\footnotetext{
${ }^{1}$ Argentina, Brazil, Chile, China, Colombia, Czech Republic, Egypt, Greece, Hungary, India, Indonesia, Korea, Malaysia, Mexico, Qatar, Pakistan, Peru, Philippines, Poland, Russia, South Africa, South Korea, Taiwan, Thailand, Turkey, and United Arab Emirates.
} 
volatility (FSB_2) and banking Z-score (FSB_3) are 11.69, 24.39 and 11.69, with the FSB 2 the least stable given the relatively large value of its standard deviation compared to that of other indicators of financial stability. In terms of correlation, we find the GDP per capita to be positively correlated with all the conventional determinants of growth but inflation. However, the correlation result appears mainly negative for GDP per capita and all the indictors of financial stability, but positive between institutional quality and GDP per capita.

\section{Methodology}

\subsection{The Model}

Sustaining the standard practice in the literature, we commence our model specification with the conventional growth regression (see also Botev et al., 2019; Creel et al., 2015; Samargandi et al., 2014).

$$
y_{i t}=a+\mu_{i}+x_{i, t}^{\prime} \beta+\varepsilon_{i, t}
$$

Equation (1) is our baseline model where ${ }^{y_{i t}}$ represent income growth measures as log of the first difference of GDP per capita, while the term $X_{\text {is a }} k \times 1$ vector of the various conventional determinants of income growth

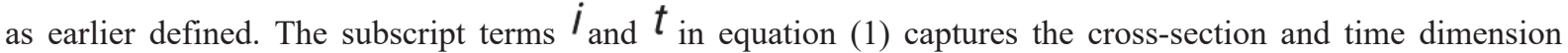
respectively, while the parameters $a$ represents constant term and $\mu$ is the country-specific fixed effect.

To address the main objective of this study, we further extend equation (1) to include the alternative indicators of financial stability.

$$
y_{i t}=a+\mu_{i}+x_{i, t}^{\prime} \beta+\lambda F S B_{i, t}+\varepsilon_{i, t}
$$

where FSB capture the various indicator of financial stability(instability) for instance non-performing loan (FSB_1), stock market volatility index (FSB_2) and banking Z-score (FSB_3).

Like equation (2), we also extend equation (1) to singly capture the role of institutional quality to understand from the individual perspective the relative potential of institutional quality for enhancing income growth compared to financial stability.

$$
y_{i t}=a+\mu_{i}+x_{i, t}^{\prime} \beta+\psi / N S T_{i, t}+\varepsilon_{i, t}
$$

Moving forward, we combine equations (2) and (3) in a single framework and extend it to include an interaction $\left(F S B^{*} I N S T\right)$ in order to capture the substitutability and complementarity roles of financial stability and institutional quality in growth process.

$$
y_{i t}=a+\mu_{i}+x_{i, t}^{\prime} \beta+\lambda F S B_{i, t}+\psi / N S T_{i, t}+\delta\left(F S B^{*} I N S T\right)_{i, t}+\varepsilon_{i, t}
$$

To ensure that the interaction term does not merely proxy for FSB and INST, we add these individual variables separately in equation (4). Whereas, the emphasis in equation (4) is on the statistical significance of the interaction coefficient (i.e. $\boldsymbol{\delta}$ ) depending on the signs on the coefficient. For a negative sign, the indication is that FSB is the more effective for enhancing income growth in country with weak institution. Saying it differently, a negative coefficient on the interaction term provides evidence of substitutability between FSB and INST. However, when the sign on the coefficient of the interaction term is positive, the likely implication is that the growth effects of FSB are enhanced in a strong institutional environment, thus supporting the complementarity of FSB and INST.

\subsection{Estimation technique}

The variant income growth regression models as specified above can be estimated using any of the standard panel data estimators namely, pooled OLS, Fixed Effects and Random Effects. But for the heterogeneity consequence of its assumption of common intercept and slope coefficients for all cross-sections, the pooled OLS has always been regarded as too restrictive in its assumption. Even when fixed effect estimator on the hand, assumes common slopes and variance but country specific, it suffers from problems of loss of degree of freedom (Baltagi, 2008). Unlike fixed effects model, the random effects have been acknowledged as less problematic in terms of degrees of freedom since it assumes common intercepts. Despite this, the random effects assumption of time invariants is considered to be strict exogeneity as it implies, that the error at any period is uncorrelated with the past, present and future (see Loayza and Ranciere, 2002; Arellano, 2003).

Although, making preference between the fixed effect model and random effect model is usually determine via the Hausman (1978) test, it must be pointed however, that neither the fixed effect model nor the random effect model has the potential to capture the dynamic feature of the data, as they can only deal with structural heterogeneity particularly in the form of random or fixed effects, while on the other hand impose homogenous 
slope coefficient across countries even though there may be substantial variations between them (Samargandi et al., 2014).

It is instructive that the relationship between financial stability and income growth is not static as expressed in equation (2). Rather, it is dynamic as the income growth is explained by it's lagged values among other determinants. Following Beck \& Levine (2004) as well as Creel et al. (2015), we rewrite equation (2) as below.

$$
y_{i t}=a+\mu_{i}+\rho y_{i, t-1}+x_{i, t}^{\prime} \beta+\lambda F S B_{i, t}+\varepsilon_{i, t}
$$

where $y_{i t-1}$ is the one-period lagged of income growth and $\rho$ is the autocorrelation coefficient while other variables remain as earlier defined. On the whole, this dynamic procedure is applicable to all the variants of income growth -financial stability models specified in equation (1) through to (4).

In line with Arellano \& Bond (1991), each of the various specified dynamic panel models can be estimated using the difference Generalized Method of Moments (GMM) estimator. However, in order to circumvent the potential bias associated with the use of difference GMM (see Alonso-Borrego and Arellano, 1999), we adopted the alternative method which is system GMM developed by Arellano \& Bover (1995) and Blundell \& Bond (1998). Indeed, the system GMM is not without its own shortcomings since the number of instruments is likely to increase exponentially with the number of time periods leading to finite sample bias. To this end, the system GMM is implemented via a collapsed instrument matrix.

\section{Empirical Findings and Discussion}

Presented in Table 3 are the empirical estimates obtained from the conventional growth regression and its various extensions that include the role of financial stability and institutional quality. In an attempt to validate the assumption of no serial correlation in the error across the variants dynamic panel models under consideration, we explore the standard specification tests in the literature (i.e. $\mathrm{AR}(1) \& \mathrm{AR}(2))$ to show that the error terms are not serially correlated. Equally confirming the validity of the instruments is the non-rejection of the null hypothesis for the Hansen J-test. Having ascertain the accuracy of each of the estimated models, we then proceed to discuss the estimates obtained. Starting with the baseline model, we follow the standard practice in the literature to replicate for our sample the similar estimations of growth regression (see Beck \& Levine, 2004; Creel et al., 2015). Essentially, we find the coefficient of physical capital, credit to private sector and inflation to be statistically viable for explaining income growth in the emerging markets.

However, while the sign or the direction of the relationship is as expected for the coefficients on physical capital and inflation for instance positive and negative respectively, it is, however, otherwise for the coefficient on credit to private sector. Although, it is only theoretically rational to predict positive impact of credit to private sector, but the fact that the result seems otherwise in the context of this study yet finds support in Creel et al. (2015) and Sotiropoulou et al. (2019). For instance, this likelihood of negative impact of credit to private sector on growth may not be unconnected to poor and inefficient credit allocation to projects that are not beneficial for economic activity and do not improve the economic growth.

Having confirmed the robustness of our sample given the consistency of our estimates with some of the estimation of growth regression in the literature, we then turn to the main objective of this study, which bothered on the role of financial stability(instability) in growth process and whether it is sensitive to the choice of the indicator of financial stability(instability) that is under consideration. Still on table 3, a look at the estimates under the extended model with (FSB) shows that the magnitude of the potential positive impact of physical capital on economic growth is relatively higher for the growth regression model that accounts for the role of financial stability compared to the growth regression model without any indicators of financial stability (i.e. baseline model). This notwithstanding, we find the coefficients on non-performing loans (FSB-1) as well as stock market volatility index (FSB 2) to be statistically significant but with negative impact on income growth. This seems to be suggesting that same as the stock market dimension, financial system instability due to nonperforming loans are likely to constitute a detrimental factor for income growth in the selected emerging countries. 
Table 3: System GMM Dynamic Panel estimation for Growth -Financial Stability Nexus

\begin{tabular}{|c|c|c|c|c|}
\hline & Baseline Model & $\begin{array}{c}\text { Extended Model } \\
\text { (FSB) }\end{array}$ & $\begin{array}{c}\text { Extended Model } \\
\text { (INST) }\end{array}$ & $\begin{array}{c}\text { Extended Model } \\
\text { (FSB*INST) }\end{array}$ \\
\hline \multirow[t]{2}{*}{ GDP/Cap-1 } & 0.0963 & 0.0234 & 0.0969 & 0.0234 \\
\hline & $(0.0632)$ & $(0.0838)$ & $(0.0622)$ & $(0.0847)$ \\
\hline \multirow[t]{2}{*}{$P K$} & $0.0033^{*} * *$ & $0.0045^{* *}$ & $0.0033 * * *$ & $0.0045^{* *}$ \\
\hline & $(0.0012)$ & $(0.0019)$ & $(0.0012)$ & $(0.0019)$ \\
\hline \multirow{2}{*}{$H K$} & 0.0003 & 0.0003 & 0.0003 & 0.0003 \\
\hline & $(0.0002)$ & $(0.0003)$ & $(0.0002)$ & $(0.0003)$ \\
\hline \multirow[t]{2}{*}{$G C$} & -0.0014 & -0.0004 & -0.0014 & -0.0004 \\
\hline & $(0.0019)$ & $(0.0029)$ & $(0.0019)$ & $(0.0029)$ \\
\hline \multirow[t]{2}{*}{$C P S$} & $-0.0011 * * *$ & $-0.0016^{* * *}$ & $-0.0011 * * *$ & $-0.0017 * * *$ \\
\hline & $(0.0003)$ & $(0.0004)$ & $(0.0003)$ & $(0.0004)$ \\
\hline \multirow[t]{2}{*}{$I N F L$} & $-0.0013 * *$ & $-0.0014 * * *$ & $-0.0012 * *$ & $-0.0014 * *$ \\
\hline & $(0.0006)$ & $(0.0005)$ & $(0.0006)$ & $(0.0005)$ \\
\hline \multirow[t]{2}{*}{ TOP } & 0.0002 & 0.0003 & 0.0002 & 0.0003 \\
\hline & $(0.0002)$ & $(0.0003)$ & $(0.0002)$ & $(0.0003)$ \\
\hline \multirow[t]{2}{*}{ FSB_1 } & & $-0.0012 *$ & & -0.0010 \\
\hline & & $(0.0006)$ & & $(0.0007)$ \\
\hline \multirow[t]{2}{*}{ FSB_2 } & & $-0.0012 * * *$ & & $-0.0018 * * *$ \\
\hline & & $(0.0002)$ & & $(0.0002)$ \\
\hline \multirow[t]{2}{*}{ FSB_3 } & & 0.0001 & & 0.0002 \\
\hline & & $(0.0002)$ & & $(0.0004)$ \\
\hline \multirow[t]{2}{*}{ INST } & & & $1.42 \mathrm{e}-05$ & 0.0147 \\
\hline & & & $(0.0125)$ & $(0.0188)$ \\
\hline \multirow[t]{2}{*}{ FSB_1*INST } & & & & $7.62 \mathrm{e}-05$ \\
\hline & & & & $(0.0010)$ \\
\hline \multirow[t]{2}{*}{ FSB_2*INST } & & & & $7.68 \mathrm{e}-06$ \\
\hline & & & & $(0.0004)$ \\
\hline \multirow[t]{2}{*}{ FSB_3*INST } & & & & -0.0004 \\
\hline & & & & $(0.0013)$ \\
\hline \multirow[t]{2}{*}{ Constant } & -0.0074 & -0.0267 & -0.0070 & -0.0265 \\
\hline & $(0.0299)$ & $(0.0477)$ & $(0.0299)$ & $(0.0482)$ \\
\hline No. of Group & 23 & 23 & 23 & 23 \\
\hline No. of Observation & 483 & 483 & 483 & 483 \\
\hline $\operatorname{AR}(1)$ & 0.002 & 0.003 & 0.001 & 0.002 \\
\hline $\operatorname{AR}(2)$ & 0.255 & 0.213 & 0.224 & 0.202 \\
\hline Hansen J-test p-value & 0.074 & 0.268 & 0.074 & 0.331 \\
\hline
\end{tabular}

Note: Reported in the lower part are the p-values of standard specification tests while Robust (Windmeijer) standard errors are in brackets such that $* * * \mathrm{p}<0.01$, ** $\mathrm{p}<0.05$, and $\mathrm{p}<0.1$.

Put differently, we find both the stock market and banking sector dimensions to financial stability(instability) as capable of causing declining income growth. This can be due to ineffectiveness in the credit allocation process, reduce profitability, and increase financial costs all of which bind the bank capital and negatively impact credit supply to the private sector and in turn declining economic growth. However, while the magnitude of the impact seems exact for both FSB_1 and FSB_2, the significance of the impact appears to be more evident in the case of FSB_2 at 1\% level of significance compared to FSB_2 which is only weakly significant and 10\% level of significance. Equally, an interesting finding is the fact that when the role of institutional quality was captured singly in the extended model, the coefficient on the institutional quality is though positive but not significant, the other estimates in the model appear not to be different from those earlier obtained in the case of baseline model.

Consequently, we further merged the various extended models in a single framework as well as extending it to include interaction term (FSB*INST) to capture both the substitutability and complementarity roles of financial stability and institutional quality in growth process. As earlier pointed out, the economic implications of the interaction term depend on its coefficient sign, and the motivation here is to gauge whether finance and institution are complements or substitutes for growth. However, the interaction term(s) becomes empirically irrelevant if found to be statistically insignificant irrespective of the sign on the coefficients. This appears to be the case in the context of this study, thus suggesting that finance-growth relationship might not be conditioned by institutional quality at least for the emerging economies but mainly when the latter is measured using rule of 
law index. However, the fact that the estimates on the interaction terms are positively signed for FSB $1 *$ INST and FSB_2*INST, suggests the potential of institutional quality as viable for alleviating the probable adverse effects of financial instability on income growth. Confirming this position is the additional results in Table 4, where we find coefficients on the interaction terms to be both positive and statistically significant in many instances, particularly suggesting that quality corruption control, political stability and voice of accountability are all viable for alleviating the probable adverse effect of non-performing loan on income growth.

Table 4: Growth -finance stability nexus with alternative measures of institutional quality

\begin{tabular}{|c|c|c|c|c|c|}
\hline & 1 & 2 & 3 & 4 & 5 \\
\hline \multirow[t]{2}{*}{ GDP/Cap-1 } & 0.0254 & -0.0177 & -0.0083 & -0.0086 & 0.0232 \\
\hline & $(0.1020)$ & $(0.1060)$ & $(0.0962)$ & $(0.1040)$ & $(0.0945)$ \\
\hline \multirow[t]{2}{*}{ PK } & $0.0049 * *$ & $0.0039 *$ & $0.0044 * *$ & $0.0048 * *$ & $0.0049 * *$ \\
\hline & $(0.0021)$ & $(0.0021)$ & $(0.0021)$ & $(0.0022)$ & $(0.0019)$ \\
\hline \multirow[t]{2}{*}{$H K$} & $0.0005^{*}$ & 0.0001 & 0.0004 & 0.0005 & 0.0004 \\
\hline & $(0.0003)$ & $(0.0002)$ & $(0.0003)$ & $(0.0003)$ & $(0.0002)$ \\
\hline \multirow[t]{2}{*}{$G C$} & -0.0018 & -0.0019 & -0.0015 & -0.0024 & -0.0014 \\
\hline & $(0.0024)$ & $(0.0019)$ & $(0.0026)$ & $(0.0026)$ & $(0.0023)$ \\
\hline \multirow[t]{2}{*}{ CPS } & $-0.0021 * * *$ & $-0.0018 * * *$ & $-0.0019 * * *$ & $-0.0019 * * *$ & $-0.0018 * * *$ \\
\hline & $(0.0004)$ & $(0.0004)$ & $(0.0003)$ & $(0.0004)$ & $(0.0003)$ \\
\hline \multirow[t]{2}{*}{$I N F L$} & $-0.0015 * * *$ & $-0.00142 * * *$ & $-0.0008^{*}$ & $-0.0011 * *$ & $-0.0014 * * *$ \\
\hline & $(0.0004)$ & $(0.0005)$ & $(0.0005)$ & $(0.0004)$ & $(0.0004)$ \\
\hline \multirow[t]{2}{*}{ TOP } & 0.0001 & -0.0001 & 0.0001 & $9.75 \mathrm{e}-05$ & 0.0001 \\
\hline & $(0.0002)$ & $(0.0001)$ & $(0.0002)$ & $(0.0002)$ & $(0.0002)$ \\
\hline \multirow[t]{2}{*}{ FSB_1 } & -0.0003 & $-0.0014 * *$ & -0.0008 & -0.0009 & $-0.0011^{* *}$ \\
\hline & $(0.0006)$ & $(0.0006)$ & $(0.0005)$ & $(0.0007)$ & $(0.0005)$ \\
\hline \multirow[t]{2}{*}{ FSB_2 } & $-0.0017 * * *$ & $-0.00158 * * *$ & $-0.0017 * * *$ & $-0.0016^{* * *}$ & $-0.0017 * * *$ \\
\hline & $(0.0002)$ & $(0.0003)$ & $(0.0002)$ & $(0.0002)$ & $(0.0002)$ \\
\hline \multirow{2}{*}{ FSB_3 } & 0.0015 & -0.0003 & -0.0002 & 0.00047 & 0.00086 \\
\hline & $(0.0009)$ & $(0.0004)$ & $(0.0003)$ & $(0.0003)$ & $(0.0006)$ \\
\hline \multirow[t]{2}{*}{ INST } & -0.0073 & $0.0339 *$ & -0.0078 & 0.0210 & -0.0003 \\
\hline & $(0.0188)$ & $(0.0175)$ & $(0.0163)$ & $(0.0219)$ & $(0.0176)$ \\
\hline \multirow[t]{2}{*}{ FSB_1*INST } & $0.0013 * * *$ & 0.0005 & $0.0008 * *$ & 0.0006 & $0.0016 * * *$ \\
\hline & $(0.0004)$ & $(0.0012)$ & $(0.0003)$ & $(0.0009)$ & $(0.0005)$ \\
\hline \multirow[t]{2}{*}{ FSB_2*INST } & -0.0003 & -0.0007 & 0.0003 & $6.87 \mathrm{e}-05$ & $-0.0004 * *$ \\
\hline & $(0.0003)$ & $(0.0004)$ & $(0.0003)$ & $(0.0004)$ & $(0.0001)$ \\
\hline \multirow{2}{*}{ FSB_3*INST } & -0.0023 & 0.0015 & -0.0011 & -0.0014 & -0.0009 \\
\hline & $(0.0014)$ & $(0.0015)$ & $(0.0008)$ & $(0.0009)$ & $(0.0007)$ \\
\hline \multirow[t]{2}{*}{ Constant } & -0.0047 & 0.0500 & -0.0037 & 0.0050 & -0.0101 \\
\hline & $(0.0454)$ & $(0.0432)$ & $(0.0465)$ & $(0.0486)$ & $(0.0424)$ \\
\hline No. of Group & 23 & 23 & 23 & 23 & 23 \\
\hline No. of Observation & 483 & 483 & 483 & 483 & 483 \\
\hline$A R(1)$ & 0.004 & 0.013 & 0.010 & 0.011 & 0.004 \\
\hline $\operatorname{AR}(2)$ & 0.341 & 0.299 & 0.129 & 0.211 & 0.258 \\
\hline Hansen J-test p-value & 0.427 & 0.286 & 0.367 & 0.288 & 0.321 \\
\hline
\end{tabular}

Note: Reported in the lower part are the p-values of standard specification tests while Robust (Windmeijer) standard errors are in brackets such that $* * * \mathrm{p}<0.01, * * \mathrm{p}<0.05$, and $\mathrm{p}<0.1$. The number $1,2,3,4 \& 5$ represent the different alternative measures of institutional quality in the growth -financial stability regression. Such that; 1 is model with control corruption as measure of institutional quality, 2 is model with government as measure of institutional quality, 3 is model with political stability and absence of violence as measure of institutional quality, 4 is model with regulatory quality as measure of institutional quality, and 5 is model with voice of accountability as measure of institutional quality

\section{Concluding remark}

Motivated by the mixed evidence on growth -finance nexus, this study uses the case of 23 emerging countries to examine the extent to which financial stability(instability) engender income growth while controlling for the role of institutional quality. Using a system GMM estimator, we explore both the banking and non-banking segments of the financial system to arrive at the followings. First, both the banking segment of the financial system captured as non-performing loan and the non-banking segment measured via stock market volatility proved to be an underlying source of instability in the financial system and capable of causing declining income growth in the 
emerging markets. Second, we find the role of institutional quality in income growth-financial stability relationship to be sensitive to the measure of institutional quality being considered. More importantly, we find the complimentary role of institutional quality for alleviation of the adverse effects of financial instability on income growth to be relatively more pronounce and statistically significant when the measure for institutional quality is defined as corruption control, political stability and voice of accountability.

\section{References}

Adu, G., Marbuah, G. and Mensah, J.T. (2013). Financial development and economic growth in Ghana: Does the measure of financial development matter. Review of Development Finance, 3, 192-203.

Ahlin, C. and Pang, J. (2008). Are financial development and corruption control substitutes in promoting growth? Journal of Development Economics, 86(2), 414-433.

Alonso-Borrego, C. and Arellano, M. (1999). Symmetrically normalized instrumental variable estimation using panel data. Journal of Business and Economic Statistics, 17, 36-49.

Alsamara, M., Mrabet, Z., Jarallah, S. and Barkat, K. (2019). The switching impact of financial stability and economic growth in Qatar: Evidence from an oil-rich country. The Quarterly Review of Economics and Finance, 73, 205-216.

Ang, J.B. (2008). Determinants of foreign direct investment in Malaysia. Journal of Policy Modeling, $30,185-$ 189.

Anwar, S. and Cooray, A. (2012). Financial development, political rights, civil liberties and economic growth: Evidence from South Asia. Economic Modelling, 29(3), 974-981.

Arellano, M. (2003). Panel Data Econometrics: Advanced Texts in Econometrics. Oxford University Press, UK.

Arellano, M. and Bond, S. (1991). Some tests of specification for panel data: Monte Carlo evidence and an application to employment equations. Review of Economic Studies, 58, 277-297.

Arellano, M. and Bover, O. (1995). Another look at the instrumental variable estimation of error-components models. Journal of Econometrics, 68, 29-51.

Baltagi, B.H. (2008) Econometric Analysis of Panel Data. John Wiley \& Sons Ltd., Chichester.

Batuo, M., Mlambob, K. and Asonguc, S. (2018). Linkages between financial development, financial instability, financial liberalisation and economic growth in Africa. Research in International Business and Finance, 45, $168-179$

Beck, T. and Levine, R. (2004). Stock markets, banks, and growth: panel evidence. Journal of Banking \& Finance, 28, 423-442.

Blundell, R. and Bond, S. (1998). Initial conditions and moment restrictions in dynamic panel data models. Journal of Econometrics, 87, 115-143.

Botev, J., Egert, B. and Jawadi, F. (2019). The nonlinear relationship between economic growth and financial development: Evidence from developing, emerging and advanced economies, International Economics, 160, 3-13.

Breitenlechner, M., Gächter, M. and Sindermann F (2015). The finance-growth nexus in crisis. Economic Letter, $132,31-33$.

Chu, L.L. (2019). Financial structure and economic growth nexus revisited. Borsal Istanbul Review, DOI: https://doi.org/10.1016/j.bir.2019.08.003

Cihak, M. and Schaeck, K. (2010). Competition, efficiency, and soundness in banking: An industrial organization perspective. Discussion Paper, No. 68S, Tilburg University, Center for Economic Research.

Creel, J., Hubert, P. and Labondance, F. (2015). Financial stability and economic performance. Economic Modelling, 48, 25-40.

Compton, R. and Giedeman, D. (2011). Panel evidence on finance, institutions and economic growth. Applied Economics, 43(25), 3523-3547.

Demetriades, P. and Law, S. H. (2006). Finance, institutions and economic development. International Journal of Finance and Economics, 11(3), 245-260.

Dilek., D., Serdar, I.M. and Yetkiner, H. (2016). Financial development and economic growth: Some theory and more evidence. Journal of Policy Modeling, accepted manuscript, http://dx.doi.org/10.1016/j.jpolmod.2016.08.001

Haini, H. (2019). Examining the relationship between finance, institutions and economic growth: evidence from the ASEAN economies. Economic Change and Restructuring, https://doi.org/10.1007/s10644-019-09257-5

Hausman, J. (1978). Specification test in econometrics. Econometrica, 46, 1251-1271.

Ibrahim, M. and Alagidede, P. (2018). Nonlinearities in financial development-economic growth nexus: Evidence from Sub-Saharan Africa. Research in International Business and Finance, Article in press.

IMF (2019). World Economic Outlook: Global Manufacturing Downturn, Rising Trade Barriers. Washington, DC: International Monetary Fund.

Kablam, S. (2010) Banking Efficiency and Financial Development in Sub-Sahara Africa, IMF Working Paper 
No. 10136.

Khan, M.A., Qayyum, A. and Sheikh, S.A. (2005). Financial Development and Economic Growth: The case of Pakistan. Pakistan Development Review, 819-837.

Kaushal, L.A. and Pathak, N. (2015). The Causal Relationship among Economic Growth, Financial development, and trade openness in Indian Economy. International Journal of Economic Perspectives, 9, 5-22.

Loayza, N. and Ranciere, R. (2002). Financial development, financial fragilty and growth. Venice: Center for Economic Studies \& Ifo Institute for Economic Research, Paper No. 684 (5), 1-35.

Madsen, J. B., Islam, M. R. and Doucouliagos, H. (2018). Inequality, financial development and economic growth in the OECD, 1870-2011. European Economic Review, 101, 605-624.

Mollaahmetoglu, E. and Akcair, B.Y. (2019). The missing link between financial development and economic growth: Financial Innovation. Procedia Computer Science, 158, 696-704.

Odeniran, S. O. and Udeaja E. A. (2010). Financial sector development and economic growth: empirical evidence from Nigeria. Central Bank of Nigeria economic and financial review vol 48/3

Ono, S. (2017). Financial development and economic growth nexus in Russia. Russian Journal of Economics, $3(3), 321-332$.

Ranjbar, O. and Rassekh, F. (2017). The impact of financial development on income convergence: An application of two exogenous growth models. Models, International Review of Economics and Finance, Accepted manuscript, http://dx.doi.org/10.1016/j.iref.2017.03.028

Rehman, M.Z., Ali, N. and Nasir, N.M. (2015). Linkage between financial development, trade openness and economic growth: Evidence from Saudi Arabia. Journal of Applied Finance \& Banking, 127-141.

Rousseau. P.L. and Wachtel, P. (2011). What is happening to the impact of financial deepening on economic growth? Economic Inquiry, 49(1),276-288

Samargandi, N., Fidrmuc, J., and Ghosh, S. (2014). Financial development and economic growth in an oil-rich economy: The case of Saudi Arabia. Economic Modelling, 43, 267-278.

Seven, H. and Yetkiner, H. (2015). Financial intermediation and economic growth: Does income matter? Economic System, http://dx.doi.org/10.1016/j.ecosys.2015.09.

Sotiropoulou, T., Giakoumatos, S.G. and Petropoulos, D.P. (2019). Financial development, financial stability and economic growth in European Union: a panel data approach. Advances in Management \& Applied Economics, 55-69.

World Bank (2019). Global Economic Prospect: Heightened Tensions subdued investment. Washington, DC: International Bank for Reconstruction and Development / The World Bank.

Yang, Y.Y. and Yi, M.H. (2008). Does financial development cause economic growth? Implication for policy in Korea. Journal of Policy Modeling, 30(5), 827-840.

Zhu, X., Asimakopoulos, S. and Kim, J. (2020). Financial development and innovation-led growth: Is too much finance better? Journal of International Money and Finance, 100, 1-24. 